\title{
Activities of scavenging enzymes of oxygen radicals in early maturation stages of Paragonimus westermani
}

\author{
Young-Bae Chung, Hi Sung Lee*, Chul Y. Song** and Seung-Yull Cho \\ Departments of Parasitology and Biochemistry*, College of Medicine, \\ and Department of Biology**, College of Natural Science, Chung-Ang University, \\ Seoul $156-756$, Korea
}

\begin{abstract}
In early maturation stages of Paragonimus westermani (metacercatiae, 4-, 8-, 12-week old worms), activities of antioxidant enzymes, such as superoxide dismutase, catalase, peroxidase and glutathione peroxidase, were examined. Specific activity of catalase was the highest in metacercariae and decreasing with age. That of superoxide dismutase was higher in metacercariae and 4-week worms. Specific activity of peroxidase was at its peak in 4-week worms while that of glutathione peroxidase was in 8-week worms. Specific activities of all these antioxidant enzymes were decreased to their lowest in 12-week old adults.
\end{abstract}

Key words: Paragonimus westermani, oxygen radical, superoxide dismutase, catalase, peroxidase, glutathione peroxidase, developmental stage

Paragonimus westermani is a trematode parasite that causes chronic inflammatory lung disease in carnivorous mammals and man. After an oral infection, excysted metacercariae penetrate intestinal wall and migrate peritoneal cavity to reach lung in $4 \sim 12$ weeks of infection. In the lung, adults are surrounded by granuloma wall. In the long processes of the parasite infections up to about 5 years, the significance of parasitic proteinases and antioxidant enzymes are increasingly regarded to be important in pathogenesis and parasite survival(Callahan $e t$ al., 1988; McKerrow, 1989; Chung et al., 1991).

Oxidant stress is a phenomenon of damaging cellular components by reactive oxygen species, such as superoxide radical $\left(\mathrm{O}_{2}^{-}\right)$, hydroxyl radical $(\mathrm{OH} \cdot)$, singlet oxygen $\left({ }^{1} \mathrm{O}_{2}\right)$ and hydrogen peroxide $\left(\mathrm{H}_{2} \mathrm{O}_{2}\right)$ which are generated in oxygen metabolism (Fridovich, 1975). The potential lethal toxicities of oxygen radicals are well illustrated (Kellogg and Fridovich, 1975; Brawn and Fridovich, 1985; Davies et al., 1987). To prevent oxidant stress, aerobic organisms are equipped with a series of defense mechanisms such as superoxide dismutase (EC 1.15.1.1, SOD), catalase (EC 1.11.1.6), peroxidase (EC 1.11.1.7) and glutathione peroxidase (EC 1.11. 1.9). In studies of Murray et al. (1979) and Murray (1981), the roles of antioxidant enzymes had been proved to be a defense mechanism of parasitic protozoa against oxidant stress of hosts. It has also been postulated that those enzymes in parasites were an evasion mechanism against oxygen-mediated damages from hosts (Callahan et al., 1988). In this connection, antioxidant systems in adult Schistosoma mansoni were more active than those in schistosomula stage. By adding exogenous antioxidants to schistosomula, they could protect themselves from toxic oxygen 
radicals in cell-free oxygen radical generator, that is, xanthine/xanthine oxidase system (Mkoji et al., 1988a \& b). Microorganisms differ greatly in their susceptibility of oxygen-mediated damages because the levels of endogenous scavenging enzymes are different each other (Thomas et al., 1988). We have previously purified and characterized $\mathrm{Cu}, \mathrm{Zn}$-superoxide dismutase in adult $P$. westermani (Chung et $a l ., 1991$ ). However, very little information is available on oxygen scavenging enzymes and their role in host-parasite interactions in paragonimiasis. We presumed that early maturation stages of $P$. westermani are challenged by different extents of oxidant stresses. To resist to different degrees of oxidant stress, each stage may be equipped with different activities of antioxidant enzymes. To examine the assump. tion, we measured the activities of oxygen radical scavenging enzymes in the early maturation stages of $P$. westermani.

Metacercariae of $P$. zestermani were obtained from naturally infected crayfish (Cambaroides similis) collected in Cholla Nam Do, Korea. Dogs were fed with 200 metacercariae and killed sequentially on the $4,8,12$ weeks after the experimental infection. The worms of each age were collected, washed with sterile cold physiological saline and stored at $-70^{\circ} \mathrm{C}$. For the preparation of crude enzymes, worms of each age were homogenized with a tissue grinder in $50 \mathrm{mM}$ potassium phosphate buffer ( $\mathrm{pH}$ 7.8). Metacercarial homogenate was sonicated additionally at $4^{\circ} \mathrm{C}$ with 20 Watt for 30 seconds, 3 times each in 30 seconds interval (Branson Sonifier, U.S.A.), Homogenates were clarified at $20,000 \mathrm{~g}$ for an hour at $4^{\circ} \mathrm{C}$ (Sorvall $\mathrm{RC}$ 5B). Supernatants were saved and used as crude enzymes. Activity of SOD was assayed by the method of McCord and Fridovich (1969); that of catalase by Aebi (1974); glutathione peroxidase by Floehe and Guenzler (1984); peroxidase by Puetter (1974). Protein contents were measured by Lowry et al. (1951). Results were shown in Tables 1-4.

In this study, we could measure the activities
Table 1. Activities of superoxide dismutase in early maturation stages of $P$. westermani

\begin{tabular}{cccc}
\hline $\begin{array}{c}\text { Developmental } \\
\text { stages }\end{array}$ & $\begin{array}{c}\text { Activity } \\
(\mathrm{U} / \mathrm{ml})^{*}\end{array}$ & $\begin{array}{c}\text { Protein } \\
(\mathrm{mg} / \mathrm{ml})\end{array}$ & $\begin{array}{c}\text { \$pecific } \\
\text { activity } \\
(\mathbf{U} / \mathbf{m g})^{* * *}\end{array}$ \\
\hline Metacercarias & 11.10 & 1.18 & 9.41 \\
4.-week worms & 16.10 & 1.70 & 9.47 \\
8-week worms & 9.20 & 1.39 & 6.52 \\
12-week adults & 14.33 & 2.55 & $\mathbf{5 . 6 2}$ \\
\hline
\end{tabular}

:t $\mathrm{U}$ : unit

U/mg : unit per milligram of protein

Table 2. Activities of catalase in early maturation stages of P. westermani

\begin{tabular}{cccc}
\hline $\begin{array}{c}\text { Developmental } \\
\text { stages }\end{array}$ & $\begin{array}{c}\text { Activity } \\
\text { (U/mg) }\end{array}$ & $\begin{array}{c}\text { Protein } \\
(\mathrm{mg} / \mathrm{ml})\end{array}$ & $\begin{array}{c}\text { Specific } \\
\text { activity } \\
\text { (U/mg) }\end{array}$ \\
\hline Metacercariae & 29.97 & 1.18 & 25.40 \\
4-week worms & 27.00 & 1.70 & 15.88 \\
8-week worms & 15.00 & 1.39 & 10.79 \\
12-week adults & 12.07 & 2.55 & 4.73 \\
\hline
\end{tabular}

Table 3. Activities of peroxidase in carly maturation stages of $P$. westormani

\begin{tabular}{cccc}
\hline $\begin{array}{c}\text { Developmentil } \\
\text { stages }\end{array}$ & $\begin{array}{c}\text { Activity } \\
(\mathrm{U} / \mathrm{ml})\end{array}$ & $\begin{array}{c}\text { Protein } \\
(\mathrm{mg} / \mathrm{ml})\end{array}$ & $\begin{array}{c}\text { Specific } \\
\text { activity } \\
(\mathrm{U} / \mathrm{mg})\end{array}$ \\
\hline Metacercariae & 140.00 & 1.18 & 118.64 \\
4-week worms & 240.01 & 1.70 & 14.1 .18 \\
8-week worms & 140.00 & 1.39 & 100.00 \\
12-week adults & 82.70 & 2.55 & 32.43 \\
\hline
\end{tabular}

Table 4. Activities of glutathione peroxidase in early maturation stages of $P$, westermani

\begin{tabular}{cccc}
\hline $\begin{array}{c}\text { Developmental } \\
\text { stages }\end{array}$ & $\begin{array}{c}\text { Activity } \\
(\mathrm{U} / \mathrm{ml})\end{array}$ & $\begin{array}{c}\text { Protein } \\
(\mathrm{mg} / \mathrm{ml})\end{array}$ & $\begin{array}{c}\text { Specific } \\
\text { activity } \\
(\mathrm{U} / \mathrm{mg})\end{array}$ \\
\hline Metacercariae & 5.80 & 1.18 & 4.90 \\
4-week worms & 9.50 & 1.70 & 5.60 \\
8-week worms & 12.10 & 1.39 & 8.70 \\
12-week adults & 2.80 & 2.55 & 1.10 \\
\hline
\end{tabular}

of four antioxidant enzymes in the early maturation stages of $P$. westermani and the changing patterns of the enzyme activities by age were also able to be compared. The activity of catalase of the parasite was comparable to other eucaryotic tissues. Unlike the present result, catalase activity has not been detected in other trematodes such as Schistosoma mansoni (Mkoji et al., 1988) or Fasciola hepatica (Barrett, 1980). The toxicity of hydrogen peroxide in 
these species may be removed through the action of cytochrome $c$-linked peroxidase and glutathione peroxidase instead of catalase.

The specific activities of antioxidant enzymes of $P$. veestermani were higher in metacercariae or 4-week worms. Glutathione peroxidase activity was, however, the highest at 8-week worms (Table 4). Of 4 stages we examined, adult $P$. westermani of 12 -week old showed the lowest level of activities of 4 enzymes. These results suggest that metacercariae and juvenile worms (4- and 8-week old) of migrating stage were exposed more to reactive oxygen species released from host immune system. These results are different from antioxidant enzymes of $S$. mansoni which were more active in adults than in schistosomula (Mkoji et al., 1988 a \& b). To the point, we think that early stages of $P$. westermani, unlike schistosomula, must generate more antioxidant enzymes to cope with oxidant stress.

It is not yet clearly known that oxygen stress against the lung fluke is evoked more in the early stage of paragonimiasis. In addition, it is also unclear whether these enzymes are really protective to exogenous reactive oxygen species. Activities of these enzymes in secretory-excretory products of $P$. westermani should be studied in the future to confirm the defensive roles of the enzymes. As Mkoji et al. (1988a \& b) did, it is therefore necessary to undertake in vitro experiments to observe the susceptibility of different stages of $P$. westermani in the oxygen radical generation system.

\section{REFERENCES}

Aebi, H. (1974) Catalase. In: Methods of enzymatic analysis. (Ed.: Bergmeyer, H.U.), 2:673-684. Academic Press, N.Y.

Barrett, J. (1980) Peroxide metabolism in the liver fluke, Fasciola hepatica. J. Parasitol., 66:697.

Brawn, M.K. and Fridovich, I. (1985) Increased suparoxide radical production evokes inducible DNA repair in Escherchia coli. J. Biol. Chem., 260:79-110.

Callahan, H.L., Crouch, R.K. and James, E.R.
(1988) Helninth anti-oxidant enzymes: A protective mechanism against host oxidants? Parasitology Today, 4:218-225.

Chung, Y.B., Song, C.Y., Lee, H.S., Kong, Y. and Cho, S.Y. (1991) Purification and characterization of a $\mathrm{Cu}, \mathrm{Zn}_{\mathrm{n}}$-superoxide dismutase from adult Paragonimus testermani. Korean J. Parasit., 29: 259-266.

Davies, K.J.A., Delsignore, M.E. and Lin, S.W. (1987) Protein damage and degradation by oxygen radicals II. Modification of amino acid. J. Biol. Chem., 262:9902-9907.

Floehe, L. and Guenzler, W.A. (1984) Assays of glutathione peroxidase. In: Methods in Enzymology (Ed.: Packer, L.), 105:114-121. Academic Press, N.Y.

Fxidovich, I. (1975) Superoxide dismutase. Ann. Rev. Biochem., 44:147-159.

Kellogg, E.W. and Fridovich, 1. (1975) Superoxide, hydrogen peroxide and singlet oxygen in lipid peroxidation by a xanthine oxidase system. $J$. Biol. Chem, 250:8812-8817.

Lowry, C.H., Rosenbrough, N.J., Farr, A.L. and Randall, R.J. (1951) Protein measurement with Folin-phenol reagent. J. Biol. Chem., 193:265275.

McCord, J.M. and Fridovich, I. (1969) Superoxide dismutase: An enzymic function for erythrocuprein (hematocuprein). J. Biol. Chem., 244:6049-6055.

McKerrow, J.H. (1989) Parasite proteinase. Exp. Parasitol., 68:111-115.

Mkoji, G.M., Smith, J.M. and Prichard, R.K. (1988a) Antioxidant systems in Schistosoma mansoni: Correlation between susceptibility to oxidant killing and the levels of scavenger of hydrogen peroxide and oxygen free radicals. Int. J. Parasitol., 18:661-666.

Mkoji, G.M., Smith, J.M. and Prichard, R.K. (1988b) Antioxidant systems in Schistosoma mansoni: Evidence for their role in protective of the adult worms against oxidant killing. Int. $J$. Parasitol., 18:667-673.

Murray, H.W. (1981) Interaction of Leishmania with a macrophage cell line: Correlation between intracellular killing and generation of oxygen intermediates. J. Exp. Med., 153:1690-1695.

Murray, H.W., Juangbhanich, C.W., Nathan, C.F. and Cohn, Z.A. (1979) Macrophage oxygen-dependent antimicrobial activity II. The role of oxygen intermediates. J. Exp. Med., 150:950-964. 
Puetter, J. (1974) Peroxidase. In: Methods of enzymatic analysis. (Ed.: Bergmeyer, H.U.), 2: 685-690. Academic Press, N.Y.
Thomas, E,L., Lehner, R.I. and Rest, R.F. (1988) Human neutrophil anti-microbial activity. $J$. Infect. Dis., 10:S450-S456.

\section{$=$ 국문초록 $=$}

\section{산소 라디칼 관렴 효소의 폐홉충 발육 단계별 활성도 변화}

중앙대학교 의 과대학 기생충학교실, 생화학교실* 및 중앙대학교 자연 과학대학 생물학과*** 정영배 - 이희성* 동철용** 조숭열

Oxygen radical은 생물체의 산소대사 과정외 부산물로 생성되어 세포내 여러 성분을 불활성화시키거나 미생 물에 대한 방어기전으로 각용한다. 기쌩충에 존재하는 antioxidant enzyme은 숙주의 방어기전에서 유러하는 oxygen radical의 독성을 제거하므로 이 효소의 환성도는 기생중의 생존에 영 향을 미친다고 생각하고 있다. 켸합

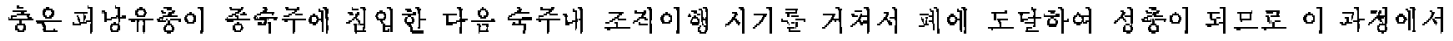
각 시기별 산소독성과 이에 대항하는 효소의 활성이 다를 것으로 추겅하였다. 폐흡종의 퍼낭유충과 감염후 4주, 8주, 12 주에 얻은 총체의 추출물울 조효소(粗醉素)로 하여 SOD, catalase, peroxidase, glutathione peroxidase 의 활성도를 촉경하였다. 각 효소의 비활성도(specific activity) 중 catalase는 되낭윧충에서 최고치였으며, SOD 와 peroxidase는 4주 풍체에서 가장 높았고, glutathione peroxidase는 8주 총체에서 높았다. 이들 4가지 antioxidant효소의 비촬성도는 감염 12주인 성충에서 모두 낮게 혹정되어 조긱 이행시기의 총체에서 더 높은 효 소 할성도를 지너고 있음을 알 수 있었다. 